\title{
THE 2007 GENERAL ELECTIONS IN KENYA Electoral Laws and Process
}

\author{
Felix Odhiambo Owuor \\ Felix Odhiambo Owuor is Senior Programme Manager of the \\ National Democratic Institute for International Affairs, Political \\ Parties Programme in Nairobi \\ e-mail: FOdhiambo@ndi.org
}

\begin{abstract}
The violence that followed the 2007 elections in Kenya sent shock waves through the country and around the world and raised questions about the Kenyan democratic landscape and the perception of stability in a region which is prone to violent conflict. Having come to power on the platform of comprehensive constitutional, legal and administrative reforms the National Rainbow Coalition government, headed by Kibaki, repeatedly reneged on promises to institute the reforms necessary to secure a new democratic dispensation and redress past imbalances. The consequence was a closely contested election, ethnic division, a flawed electoral process, a weak institutional framework and post-election violence that resulted in death, displacement and the destruction of million of dollars worth of property. This paper analyses the political and electoral environment in which the elections were held and attempts to explore the legal and constitutional framework governing elections in Kenya as well as to make recommendations for the democratisation of the electoral process.
\end{abstract}

\section{INTRODUCTION}

The consequences of Kenya's fourth multiparty elections, held on 27 December $2007,{ }^{1}$ are proof that although regular elections may be a critical element of a democracy they are not, in themselves, a guarantee of sustainable democracy. Despite the fact that the country had held elections faithfully and religiously since the attainment of independence in 1963, the 2007 elections and their immediate aftermath led to questions about the viability of institutional mechanisms in

1 Previous multiparty elections were held in 1992, 1997, and 2002. 
Kenya as safeguards of free and fair elections. Cumulatively, the problems which emerged pointed to the failure, over the years, to address the legal and structural weaknesses in the election system. At the centre of these failures were two separate but interrelated weaknesses: the constitutional, legal and administrative framework governing elections and the inability of the Electoral Commission of Kenya (ECK) to facilitate a free and fair election.

All these factors have renewed, with vigour, the debate that has persisted in Kenya since 1992 about the need for a comprehensive review of the country's Constitution and for pertinent reforms that reflect the new multiparty dispensation. In the short term, however, and because of the failures of the ECK, the Post Election Negotiation Committee, headed by former United Nations Secretary General Kofi Annan, recommended the establishment of various commissions to consider aspects of Kenya's political, social and economic system.

Of particular importance was the establishment of the International Review Commission (IREC) headed by Johann Kriegler, retired South African Constitutional Court judge and the chair of South Africa's first Independent Electoral Commission. The Kriegler Commission comprised seven members, four of them representing the Orange Democratic Movement (ODM) and the Party of National Unity (PNU). Their brief was to investigate all aspects of the 2007 elections and prescribe reforms that would guarantee transparency, sustainability and fairness in subsequent elections. Another important commission established after the 2007 election was the Waki Commission on post-election violence.

\section{POST-ELECTION PROBLEMS IN KENYA IN PERSPECTIVE}

To begin to understand the institutional failures in Kenya the proper starting point is to recap the events leading up to the 2007 elections. It is now widely accepted that the Kenyan state was built on quicksand, and the 2007 elections were merely the mechanism of destruction of a nation whose foundation was shaky. As various commentators, among them the Kriegler team, have noted, a number of factors contributed to the disastrous elections, the central one being the now defunct ECK.

\section{Tracing the problem: polling day activities}

- In general the proceedings on election day went well. Kenyans turned out in large numbers to vote, electoral materials were supplied well in advance to most polling stations and the conduct of the ECK personnel during the voting period was exemplary. 
- Essentially, the problems began on 28 December, when results began to trickle in from the various constituencies. By that evening the preliminary results released by the ECK revealed a 1-million vote gap between the ODM-Kenya candidate, Raila Odinga, and the PNU candidate, sitting President Mwai Kibaki.

- Then things began to go wrong.

- Returning officers covering areas regarded as Kibaki strongholds disappeared, causing delays in the transmission of results from Central and Eastern provinces.

- When the results from Central and Eastern provinces were finally released there were clear disparities between the provisional results released at the polling stations and the official results contained in the statutory forms at the ECK national tallying centres.

- Other anomalies included the submission of photocopied results contrary to the legal requirements, the absence of the signatures of presiding officers and party agents and of the ECK stamp that was crucial to authenticating the documents, and the correction of results that revealed discrepancies, for example, in areas that reflected a turnout of more than $100 \%$.

- As a consequence the final results released by the ECK on 30 December in response to pressure from both the PNU and the ODM-K revealed that President Kibaki had won with 4,5-million votes against Raila's 4,3 million.

- Within an hour after the ECK's announcement President Kibaki was sworn in at State House, Nairobi, for a second five-year term. Within minutes fighting and mass protests broke out in different parts of the country, with the majority denouncing the results.

\section{The Independent Review (Kriegler) Commission Report}

The report of the Kriegler Commission, set up to examine the integrity of the entire electoral process, including voter registration, voting, the counting process and dispute resolution, was explicit and categorical about the failure of the ECK to supervise the elections professionally and competently.

In fact, the problem began far earlier, when President Kibaki unilaterally appointed the 22 commissioners to serve on the ECK and, in so doing, eroded the perception of neutrality the commission had cultivated since 2002 and flouted the terms of the 1997 Inter Party Parliamentary Group Agreement (IPPG), which required the parties to nominate the commissioners. Regrettably, 
because the agreement was not entrenched in law Kibaki was able to replace existing commissioners with people who, by and large, had no previous electoral experience and who, for the most part, did not comply with the requirements of neutrality and professionalism.

Despite this, because the conduct of the ECK during and after the 2002 general elections and the 2005 referendum had been exemplary and above board both Kenya and the rest of the world believed the commission would be up to the task of ensuring a free and fair election in circumstances where competition would be fierce. This was not to be.

The National Assembly and Presidential Elections Act (Cap 7 of the Laws of Kenya) gives enormous powers to the returning officer with respect to elections at the constituency level. Apart from supervising such elections the returning officer has the power and discretion to extend voting hours and to order a recount before the results are announced.

With respect to the results, the returning officers and party agents must complete a series of statutory forms. With regard to the presidential election the 22 commissioners are jointly regarded as the returning officer for the purposes of tallying the votes and announcing the results. Evidently, and by the admission of the ECK, serious anomalies occurred during the tallying process at the constituency level and these, according to the Kriegler Commission's report, fundamentally affected the result of the presidential election.

While the poor tallying of results affected most constituencies the problem was particularly predominant in Central Province. In Juja constituency, Central Province, for example, provisional results indicated that the total number of votes for Kibaki was 48 293, however, at the ECK tallying centre the result for Juja was amended to 100390 votes, the figure the ECK relied on. This situation was repeated in most constituencies in central Kenya. In Maragua the number of votes cast was greater than the total number of registered voters, which forced the ECK to reject the result.

One of the decisions the commission had to make was whether the returning officers had made false declarations that were criminally actionable?

The Kriegler Commission declared categorically that the incompetence and ineptitude of the ECK was largely to blame for the election fiasco. While there was no evidence of misconduct at the national tallying centre, the process at the constituency level was so irredeemably flawed that it was almost impossible to judge who had won the election.

Accordingly, the commission recommended that the ECK be disbanded and replaced with a leaner, more efficient body. Appointments should be vetted by an independent body, preferably Parliament. 


\section{THE LEGAL FRAMEWORK GOVERNING ELECTIONS IN KENYA}

The present legal regime governing elections dates back to 1991 when, in response to local and international pressure, the Constitution was amended to reintroduce multiparty democracy. Section 2A of the Constitution, enacted by the Kanu regime in 1982 and outlawing the formation of other political parties, effectively making Kenya a one-party state, was repealed. The effect of the constitutional amendments enacted during the Kenyatta and Moi regimes was to centralise power in the executive, to entrench a monolithic system of government, and to curtail fundamental rights and freedoms, including the freedom of association and assembly (Kadima \& Owuor 2006).

The repeal of s2A and the subsequent reintroduction of multiparty politics, although hailed as a major political landmark, were, regrettably, not accompanied by constitutional, legal or administrative reforms. Consequently, the country embraced multipartyism without the reforms required for a true multiparty democracy.

The successes of the 2002 elections and the 2005 referendum further created a belief that the electoral system was perfect. In fact, it was legally and institutionally weak, faults that were glaringly exposed by the hotly contested elections of 2007.

\section{Kenya's obligations in terms of international and regional standards}

The significance of elections as a critical element in a democracy is recognised and enshrined in various international instruments, to which Kenya is a signatory. Prominent among these is the Universal Declaration of Human Rights, which explicitly provides, in Article 21, that 'everyone has a right to take part in the government of his country, directly or through freely chosen representatives'. The importance of elections is further affirmed in subs 3 of the declaration, which provides that 'the will of the people shall be the basis of authority of government: this will shall be expressed in periodic and genuine elections which shall be by universal suffrage and shall be held by secret vote or by equivalent free voting procedure'.

Among the international instruments that underscore the principles of citizen participation in democratic governance are: the International Covenant on Civil and Political Rights, the International Convention on the Elimination of All Forms of Racial Discrimination, the Convention on the Elimination of All Forms of Discrimination Against Women and the Convention on the Rights of Persons with Disabilities. There is also a host of regional instruments whose 
objectives, like those of the international instruments, is to promote and recognise the participation of citizens in governance processes. These regional instruments include the African Charter on Human and People's Rights, the Declaration on the Principles Governing Democratic Elections in Africa, and the African Charter on Democracy, Elections and Governance.

While Kenya is a signatory to these important instruments it lags behind in matters of enforcement and implementation. The problem lies in the fact that in the Kenyan legal system treaties negotiated and signed by the executive do not become part of the country's laws until they have been adopted by Parliament. The challenges of the 2007 elections and the problems associated with it now demand that Kenya move expeditiously to join the community of nations by ratifying and adopting these instruments. Besides, a widely acceptable norm with regard to the enforcement of obligations arising from international instruments is that states cannot circumvent their obligations and commitments arising from international agreements by failing to enact enabling legislations.

\section{ELECTORAL LAWS IN PERSPECTIVE}

The legal framework governing elections in Kenya can be divided into two parts. The first consists of laws enacted solely to govern elections. These include the Constitution of Kenya, The National Assembly and Presidential Elections Act, the Local Government Act, and the Election Offences Act.

The second set of laws, are those that, although they were not enacted expressly to deal with elections, nevertheless have a collateral impact on them and directly affect the process. They are: the Kenya Broadcasting Corporation Act, the Penal Code, and the Registration of Persons Act, among others.

\section{Post-election procedures}

\section{Internal evaluation}

In the immediate post-election period the ECK embarks on the routine work of retrieving material, storing it, paying staff, and assessing the election process. Since 2002 it has also conducted a two-phase post-election evaluation. The first phase is internal and consists of collecting information from the field and engaging the regional officers. The second includes stakeholders and provides an opportunity to discuss possible changes in the process. 


\section{Dispute resolution}

Section 44 of the Constitution gives the High Court jurisdiction to hear and rule on election petitions. This jurisdiction is extended by s 19 of the National Assembly and Presidential Elections Act (1998 Cap 7), which provides for the determination of whether the election of the president is valid. A petition to challenge the validity of the presidential election is heard by a bench consisting of three judges. A petition to challenge the validity of the election of a member of the National Assembly is heard by one judge. Rule 36 of the National Assembly Elections (Election Petition) Rules requires the attorney general or a person appointed by the attorney general to be present during all such cases.

\section{Procedure for election petitions}

Section 20 of the National Assembly and Presidential Elections Act requires that any election petition be presented and served within 28 days of the date of publication of the result of the election in the Gazette. A petition seeking a declaration that a seat in the National Assembly has not become vacant must be presented and served within 28 days of the date of publication of a notice declaring the seat vacant. However, a petition to seek a declaration that a seat in the National Assembly has become vacant may be presented at any time.

Finally, the law requires that within three days from the presentation of the petition the petitioner must provide security for any costs that may be incurred. Failure to comply with this deadline results in the dismissal of the petition. The Court of Appeal has held that failure to deposit security in time is not a mere irregularity to be waived by parties, in terms of s21(3) of the National Assembly and Presidential Elections Act, it leads to the dismissal of the petition. The courts have taken a rigid view of the technical rules, holding that there is no remedy for non-compliance. In addition, petitions may not be amended outside the stipulated period and parties' names must be strictly correct.

The procedural and technical ramifications of compliance required from parties wishing to lodge an election petition make the process cumbersome and it can take years for judgement to be handed down. To begin with, petitioners are expected to effect personal service on the respondents and many election petitions have been thrown out because of failure to comply with this requirement. Secondly, there is no court that deals specifically with election petitions matters - the chief justice must constitute a bench to determine electoral disputes.

The fact that the judiciary is currently coping with a serious backlog has further retarded decision-making in cases of electoral disputes. In 2003, for example, 34 election petitions were filed and most of the cases were only decided in $2006 / 2007$, while three have still to be heard. 


\section{REFORMING THE ELECTORAL PROCESS: POST-ELECTION INITIATIVES}

\section{Completion of the constitutional review process}

Agitation for a comprehensive review of the Constitution began in 1990 and today, almost two decades later, the country still does not have a new constitution. The four items singled out by the Panel of Eminent African Personalities as needing to be addressed as a matter of urgency to forestall future conflicts are all key constitutional issues that have been the subject of significant debate.

Towards the end of 2008 Parliament passed the Constitution of Kenya Review Act to pave the way for the completion of the constitutional review. The Act provide for the nomination by a parliamentary select committee (PSC) and appointment by the president of a committee of seven, three of them international experts. On 22 January 2009 the PSC selected three top African lawyers to serve on the review commission.

\section{Two new commissions}

'It lacks functional efficiency and is incapable of properly discharging its mandate' Kriegler Commission Report.

This was the finding of the Independent Review Commission on the ECK. The commission recommended that the body be dissolved and replaced with a new body, complete with a new outlook, name and ethos.

In a move towards implementation of this recommendation Parliament passed a constitutional amendment in November 2008 abolishing the ECK and replacing it with two interim commissions, the Interim Independent Commission and the Interim Boundary Commission. The two commissions will be constituted by Parliament and will divide between them the core functions of the former ECK, namely, electoral supervision and boundary delimitation. The two commissions will work for two years, at the end of which they will be dissolved to pave the way for more permanent commissions.

\section{The Waki report on post-election violence}

The commission to investigate the post-election violence was set up in 2008 in response to a recommendation by the Panel of Eminent African Personalities. It was headed by Justice Waki, who, in a detailed report, recommended that a local 
tribunal be set up to investigate 10 people suspected to be key to the instigation of violence. Failing that, the commission recommended that the suspects be tried in the International Criminal Court (ICC).

The report has posed problems for the government, with parliamentarians divided over whether a local tribunal should be set up, which would require a constitutional amendment providing for the entrenchment of such a tribunal, or whether the matter should be referred to the ICC. As a result a Bill relating to the establishment of a local tribunal and debated in Parliament on 5 February 2009 failed to win the mandatory two-thirds of the vote and will have to be tabled again.

\section{Other proposals for reform}

\section{Reform and consolidation of election laws}

As stated above the restoration of the multiparty system in 1992 was not accompanied by corresponding reforms and the country's laws continue to favour the incumbent party and president. Among the reforms that are needed are an electoral Act that codifies and consolidates all laws pertaining to elections and spells out clearly and concisely the procedural and substantive matters relating to elections.

\section{Electoral System}

Kenya's first-past-the-post single-member constituency electoral system has been the subject of debate for some time. The main criticism levelled against it is the high stakes associated with the winner-takes-all system, which, it is contended, are responsible for problems such as ethnicity, corruption, electoral fraud and violence.

Both the Bomas and Kilifi constitutional drafts contained a recommendation that a mixed member proportional representation (MMP) system be introduced, combining constituency-based elections with nominations based on proportional representation.

\section{Introduction of a two-chamber Parliament}

The introduction of a two-chamber Parliament (Senate and the House of Representative) would go a long way to dealing with the defects associated with the present electoral system and constituency boundaries. In the past the abolition of existing constituencies and changes to the electoral system have proved to be extremely emotive issues that have met with serious resistance.

The introduction of the Senate, as the upper house, with seats shared equally on a provincial/regional basis would compensate provinces affected by the 
creation of new constituencies. The fact that constituencies would be retained while representation issues would be addressed by the creation of the second chamber would allay the fears of those who are resistant to change. The creation of two chambers would, however, require a constitutional review or amendment.

\section{Compliance with the Political Parties Act}

The Political Parties Act is arguably the single most important piece of legislation introduced since the restoration of multiparty politics. It introduces reforms of the running and management of political parties which will have the effect of institutionalising their operation. To facilitate successful implementation of the Act strict enforcement and compliance mechanism should be put in place to ensure that political parties abide by its salient provisions. Parties must also develop clear rules for nomination procedures and deposit these with the ECK, whose functions should be extended to include supervising party elections.

\section{Post-election dispute resolution}

Two reforms should be put in place with regard to post-election dispute resolution.

- Enhancing the independence of the judiciary

After the disputed 2000 presidential election in the United States the then-vice-president, Al Gore, while disagreeing with the verdict of the Supreme Court, stated that he accepted it because of the faith he had in the American system. Faced with a similar situation after the 2007 elections in Kenya the ODM refused to seek redress by petitioning the courts, citing a lack of faith in the independence of the judiciary. Measures should be put in place to enhance the image of the judiciary as a neutral and impartial arbiter in all matters, including those related to elections. To avoid lengthy delays in the settlement of election disputes an electoral complaints tribunal should be set up to deal exclusively with such disputes.

- Prosecutorial powers of the ECK

The powers of the ECK should be enhanced to include a prosecutorial role in all election-related matters, as is the case in India. Increasing the powers of the ECK will ensure its effectiveness, particularly with regard to issues related to the enforcement of the Electoral Code of Conduct. 


\section{Comprehensive constitutional review or targeted reforms}

Comprehensive constitutional review in Kenya and the enactment of a new constitution has been very elusive. Although the clamour began in 1991 and peaked during the 2005 referendum the country still does not have a new constitution. The Kriegler Commission report confirmed the long-held belief in the political domain that Kenya has a weak legal and structural framework coupled with inequality in resource allocation. To restore the country to the path to sustainable democracy urgent steps should be taken either to revive the constitutional review process or to consider targeted reforms of key institutions and sectors.

\section{- REFERENCES -}

Kadima, D (ed). 2006. The Politics of Party Coalition in Africa. Johannesburg: EISA.

\& Owuor, F. 2006. 'The National Rainbow Coalition: Achievements and Challenges of Building and Sustaining a Broad-Based Political Party Coalition in Kenya'. In D Kadima (ed). The Politics of Party Coalition in Africa. Johannesburg: EISA.

Kriegler, J. 2008. Independent Review Commission Report.

United Nations. 1948. Universal Declaration of Human Rights. Document a/810, p 75 .

Waki, P. 2008. Report of the Independent Review Commission http:/ / wikileaks.org/ wiki/kenya:_waki_commission_of_Inquiry_into_Post-Election_Violence_ final_report_15_Oct_2008

\section{Legislation}

Political Parties Act no 10 of 2007

Constitution of Kenya Act of 2001

National Assembly and Presidential Elections Act of 1998

Election Offences Act (Cap 66)

Local Government Act (Cap 265)

Kenya Broadcasting Corporation Act (Cap 221)

Penal Code (Cap 63)

Registration of Persons Act (Cap 107)

Constitution of Kenya Review Act of 2008. 